\title{
COVID-19: A Bibliometric Analysis and Insights
}

\author{
Prerna Gautam \\ Department of Operational Research, \\ Faculty of Mathematical Sciences, University of Delhi, Delhi -110007, India. \\ E-mail: prerna3080@gmail.com \\ Sumit Maheshwari \\ Department of Operational Research, \\ Faculty of Mathematical Sciences, University of Delhi, Delhi -110007, India. \\ E-mail: sumitduor@gmail.com

\section{Singh Mathuria Kaushal-Deep} \\ Department of Neurosurgery, \\ Sher-i-Kashmir Institute of Medical Sciences, Soura, Srinagar, 190011, India. \\ E-mail:drkdsm@gmail.com \\ Abdul Rashid Bhat \\ Department of Neurosurgery, \\ Sher-i-Kashmir Institute of Medical Sciences, Soura, Srinagar, 190011, India. \\ E-mail: seven_rashid@ rediffmail.com \\ Chandra K. Jaggi \\ Department of Operational Research, \\ Faculty of Mathematical Sciences, University of Delhi, Delhi -110007, India. \\ Corresponding author: ckjaggi@yahoo.com
}

(Received July 16, 2020; Accepted July 27, 2020)

\begin{abstract}
The current outbreak of the coronavirus disease has left the whole world traumatised. The illness triggered by the novel coronavirus is named as COVID-19. It is pre-fixed with the word "novel" because it comes under the new strain of the virus that has not been reported before. This virus outbreak has disrupted human life in the most petrifying way worldwide. The present study aims to analyse the work done in this field through a state-of-the-art review of articles based on COVID-19 and discuss the current trends in the epidemiology of this disease entity with special reference to India and the effects of this pandemic on the environment. The time frame selected for review is the beginning of this pandemic to April 10th, 2020. Scopus ${ }^{\circledR}$ database is used to carry out the analysis. Moreover, the most contributed authors, institutions, countries, etc. are showed through the analysis. The purpose of this review is to get an idea about the direction of the flow of current research, the association of various authors with each other, the role of collaboration between several institutions and the position of India in current explosive ongoing research.
\end{abstract}

Keywords- COVID-19, Bibliometric analysis, Research methodology, Literature review.

\section{Introduction}

A contagious disease caused by novel coronavirus (SARS-CoV-2) emerged in late December 2019 in Wuhan, China. This disease exploded rapidly in China and world (Lai et al., 2020; Wang et al., 2020a). The illness caused by the novel coronavirus was named as COVID-19 (coronavirus disease 2019). On March 12th, 2020, the World Health Organization (W.H.O.) professed COVID-19 as a 
International Journal of Mathematical, Engineering and Management Sciences

Vol. 5, No. 6, 1156-1169, 2020

https://doi.org/10.33889/IJMEMS.2020.5.6.088

pandemic. According to a recent Chinese study, about $80 \%$ of patients present with mild disease and the overall case-fatality rate is about $2.3 \%$ but reaches $8.0 \%$ in patients aged 70 to 79 years and $14.8 \%$ in those aged greater than 80 years (Wu and McGoogan, 2020). However, there is probably an important number of asymptomatic carriers in the population, and thus the mortality rate is probably overestimated. The United States of America (U.S.A.) (more than three million cases), Brazil (more than two million cases), India (more than one million cases), Russia (more than half of the million cases), South Africa, Peru, Mexico, Chile, Spain, UK, Iran, Pakistan, Saudi Arabia, Italy, Turkey, Bangladesh, and Germany (with each having over $200 \mathrm{~K}$ cases) are currently the worst affected countries (as of July 20th 2020 as per WHO report). Thus, there is an urgent need to combat this virus to contain its effect in symptomatic patients and to decrease the duration of virus carriage to limit the transmission in the community. There are around 22 countries where this virus affected more than $100 \mathrm{~K}$ people until July $20^{\text {th }} 2020$ and 41 countries with around $50 \mathrm{~K}$ cases. The total global number of COVID-19 cases has surpassed 14 million from the WHO report on July $20^{\text {th }}, 2020$.

Unfortunately, no drug is $100 \%$ efficacious in treating this infectious disease; several vaccines are under trial in many countries but have yet to be approved to treat human coronaviruses. Several options have been envisaged to control or prevent emerging infections of 2019-nCoV as per the C.D.C. (Centers for Disease Control and Prevention) and ClinicalTrials.gov including vaccines (B.C.G. vaccine), monoclonal antibodies (sarilumab), oligonucleotide-based therapies, peptides, interferon therapies, antibiotics (azithromycin, hydroxychloroquine), antihelminthics (ivermectin) and antiviral (favipiravir, ramdesivir, lopinavir-ritonavir) drugs. However, new efficacious interventions specifically targeted against COVID-19 are likely to require months to years to develop. Rushdi and Serag (2020) diagnostic testing aspects of mathematical epidemiology culminate in a timely application to and a discussion of the contemporary worldwide COVID19 pandemic. This article is based on methodology proposed by Mayring (2000). Section 2 gives a quick tour of the adopted methodology. Section 3 discusses the descriptive analysis and material evaluation along with the current epidemiological insights. Section 4 provides an enriched discussion of the topic that elaborates the characteristics of the coronaviruses further. Section 5 presents a conclusion of the review study.

\section{Research Methodology}

The present study aims to analyse the work done in this field through a state-of-the-art review of articles based on COVID-19 and discuss the current trends in the epidemiology of this disease entity with special reference to India and the effects of this pandemic on the environment. The essential steps for the literature review studies are material collection, descriptive analysis, category selection, and material evaluation as has been defined in the landmark book by Mayring (2000). This is a standard approach and has been adopted in several previous studies for analysing the studies on a particular area of interest (Seuring and Müller, 2008; Gao et al., 2017). With the help of a literature review, it is easy to identify the conceptual content of the research area. The first step of the research methodology is a material collection that gives an idea about the data collection with regards to that particular topic. In this step, we clarify the source for the data collection. For this study, we have collected the data from the Scopus ${ }^{\circledR}$ database until April 10th, 2020. We have summarised all the past studies related to the COVID-19 obtained from the Scopus ${ }^{\circledR}$ database. The search was performed on April 10th, 2020, and finally, we included 581 articles, published since the beginning of this topic. 
International Journal of Mathematical, Engineering and Management Sciences

Vol. 5, No. 6, 1156-1169, 2020

https://doi.org/10.33889/IJMEMS.2020.5.6.088

This paper adopts a systematic literature review approach to understand past studies related to COVID-19. This paper summarises the most contributed authors, country, and journals in the field of COVID-19 by analysing recently published articles from different publishers. Also, with the help of VOSviewer ${ }^{\circledR}$ software, we visualised the authors, co-authors and institute network visualisation. The distance between two authors in the visualisation approximately indicates the relatedness of the authors in terms of co-citation links. In general, the closer two authors are located to each other, the stronger their relatedness. The strongest co-citation links between authors are also represented by lines. Table 1 shows how the 'search' keywords were used in the Scopus ${ }^{\circledR}$ database. The total number of papers was 1899 , efficient to conduct the review, however, we carefully compiled these results and removed the repetition of the papers, non-English language papers, editorials, chapters, and thus, the final sample of papers included in the study for bibliometric analysis is 581. The total number of articles for a detailed systematic review is 33 . The inclusion criteria for the systematic review is based on the articles that have at least ten citations and published in a high-quality journal.

Table 1. Search keywords performed on the Scopus ${ }^{\circledR}$ database

\begin{tabular}{|l|c|}
\hline Search Keywords & Number of articles \\
\hline "COVID-19" OR “COVID19” & 1031 \\
\hline "SARS-COV-2” & 319 \\
\hline "Coronavirus disease” OR “Corona virus disease” & 510 \\
\hline "Novel Corona Virus disease” OR "Novel Coronavirus disease” & 39 \\
\hline Total number of search articles & 1899 \\
\hline $\begin{array}{l}\text { After removing the repeated articles, removing other than English language articles, letters, book chapters, } \\
\text { and Editorial material }\end{array}$ & 581 \\
\hline
\end{tabular}

\section{Observations}

\subsection{Descriptive Analysis}

This section gives the basic idea about the general statistics based on the articles on COVID-19 which has been collected from the Scopus ${ }^{\circledR}$ database. In this section, we summarise the top authors, countries, and institutes that contributed to the field of COVID-19. Since the topic is novel for the researchers and practitioners, therefore, the amount of published work is relatively less.

From the collected data compiled in Figure 1, it can be seen that most of the publications on COVID-19 are contributed by China. In this category, United States, United Kingdom, Italy, and Canada have the second, third, fourth, and fifth positions, respectively. All the top 15 countries are represented in Figure 1. In the field of COVID-19, Mahase, E published the highest number of articles. Rimmer, A, Hsueh, PR, Iacobucci, G, and Day, M hold the second, third, fourth, fifth position, respectively (Figure 2). These results are dynamic as the consideration of the number of papers is till April 10th, 2020. There are not many articles from India at present on COVID-19. Most of them have been in the form of case reports and guidelines issued by Indian Council of Medical Research (ICMR) which is also acting as one of the main advisory bodies to the Indian Government in controlling this pandemic. Figure 3 shows the most contributed journal in the field of Covid-19 based on the number of publications in Scopus index journals. 
International Journal of Mathematical, Engineering and Management Sciences

Vol. 5, No. 6, 1156-1169, 2020

https://doi.org/10.33889/IJMEMS.2020.5.6.088

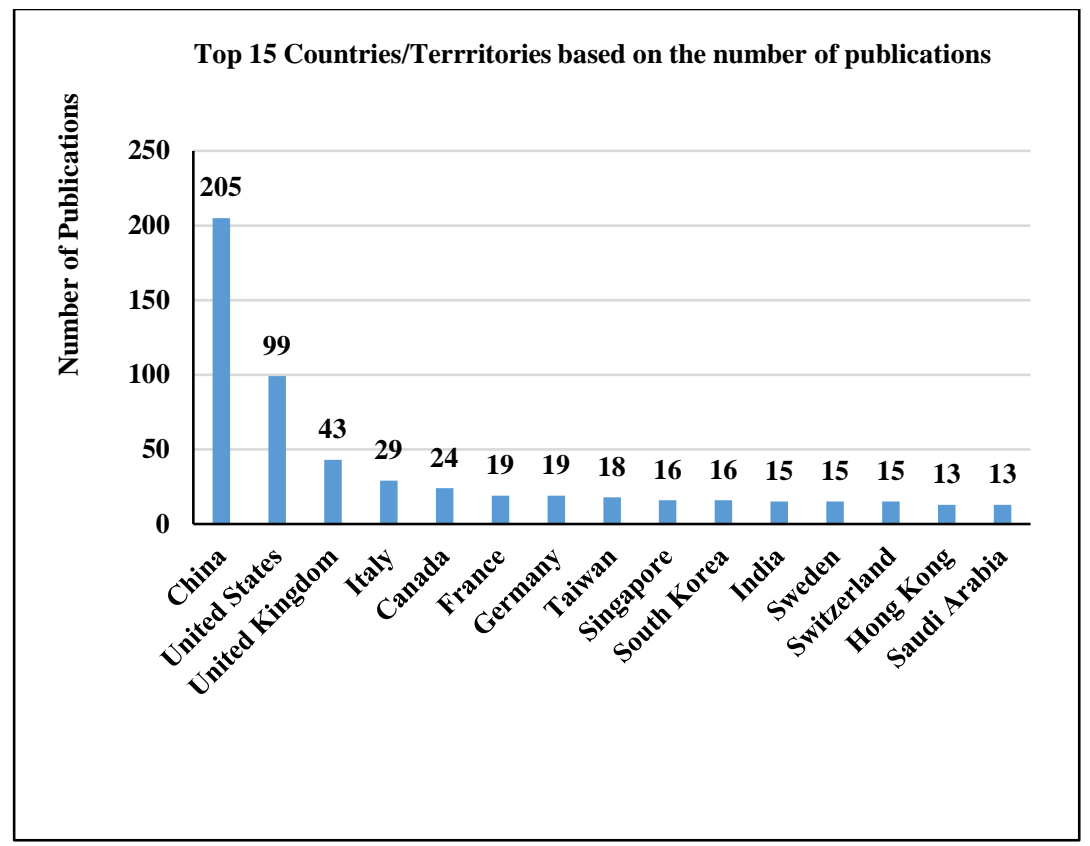

Figure 1. Contributing countries/territories in the field of COVID-19

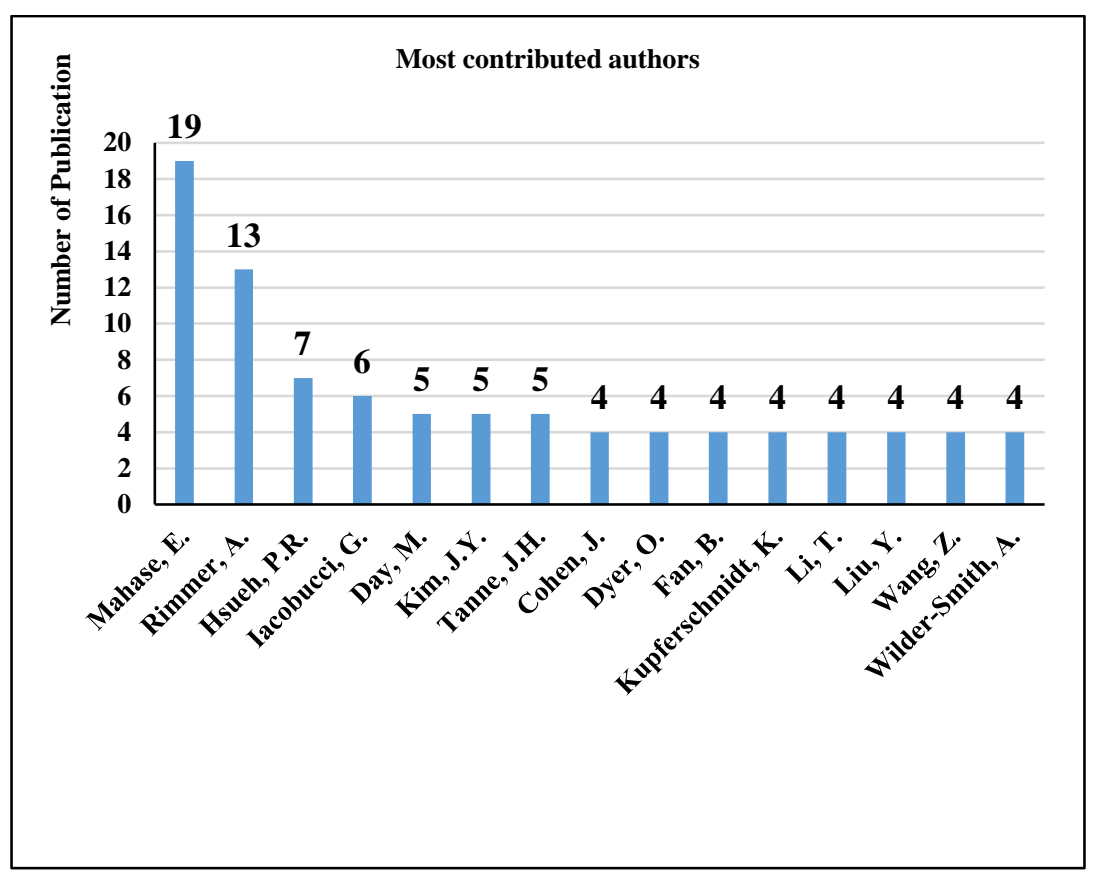

Figure 2. Most contributing authors in the field of COVID-19 
International Journal of Mathematical, Engineering and Management Sciences

Vol. 5, No. 6, 1156-1169, 2020

https://doi.org/10.33889/IJMEMS.2020.5.6.088

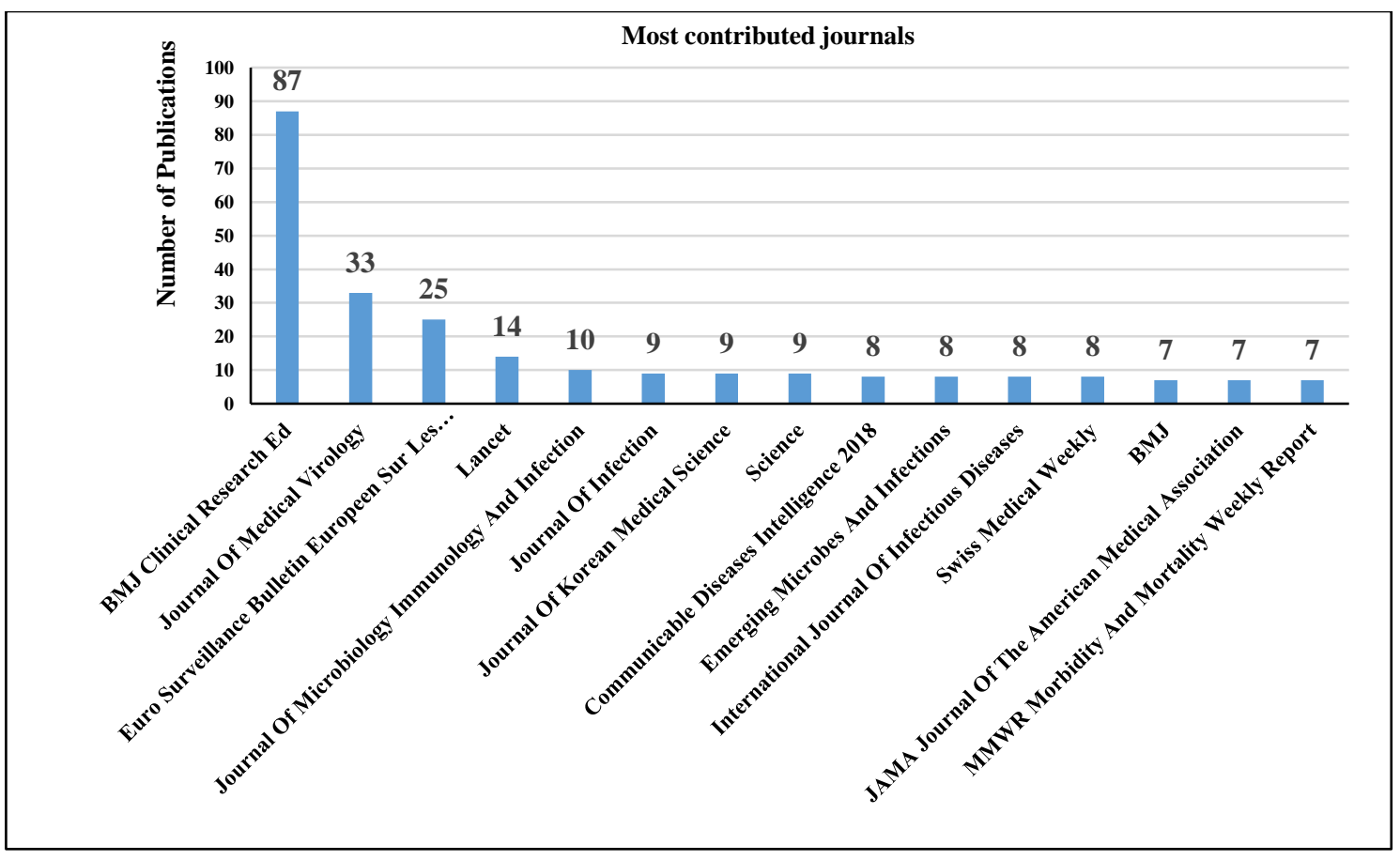

Figure 3. Most contributed journals in the field of COVID-19

\subsection{Material Evaluation}

In this section, we have summarised the network visualisation based on most contributed author, co-author (Van Eck and Waltman, 2010), and institute in the field of Covid-19 with the help of VOSviewer® software.
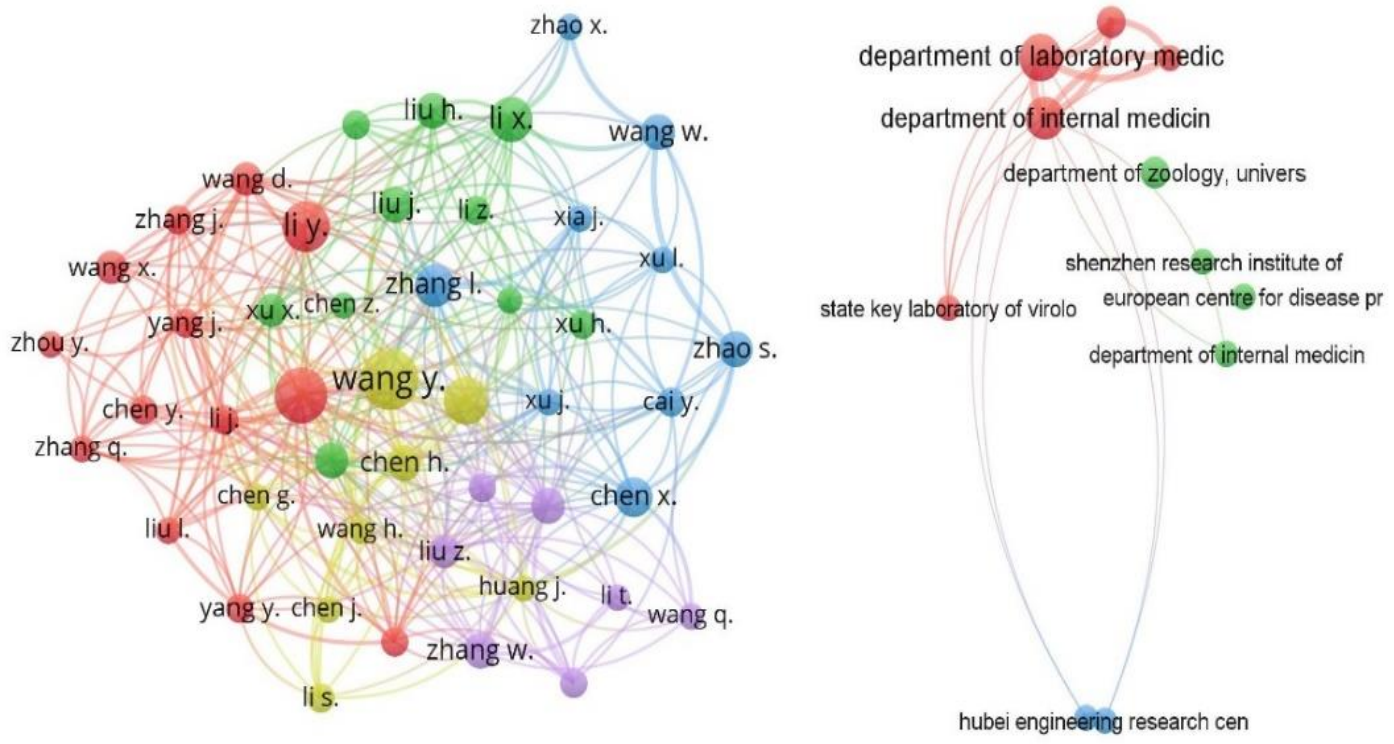

Figure 4. Network visualisation between the contributed authors \& institutes in the field of COVID-19 by VOSviewer $^{\circledR}$ 
International Journal of Mathematical, Engineering and Management Sciences

Vol. 5, No. 6, 1156-1169, 2020

https://doi.org/10.33889/IJMEMS.2020.5.6.088

Figure 4 shows the network visualisation. This section also lists the contributing authors not only from the medical field but from various others as well. The distance between two authors in the visualisation approximately indicates the relation of the authors in terms of co-citation links. In general, the closer two authors are located to each other, the stronger their relation in terms of cocitations. Also, the strongest co-citation links between authors are represented by lines.

\subsection{Current Epidemiological Insights in COVID-19}

From the point of statistical analysis, it is observed that the number of patients suffering from COVID-19 is increasing rapidly. If the number of patients crosses the limit of the medical facilities available in the country, then the situation will turn more dangerous, and it will not be easy to control. Therefore, in any country, if the number of patients suffered from COVID-19 is less than the medical facilities available in that country, then we can conclude that the situation is under control. Despite any such favoring statistics, the citizens must take proper precautions because of the exponential growth of this pandemic. Figure 5 shows two situations; the first one shows if the maximum number of patients is below the line, then the situation is under control, but on the other hand, if the curve is above the line then it will infer an out of control situation. Further, for an out of control situation the virus spread will increase exponentially that will lead to damage in terms of almost everything viz. health, wealth, peace, economy, etc.

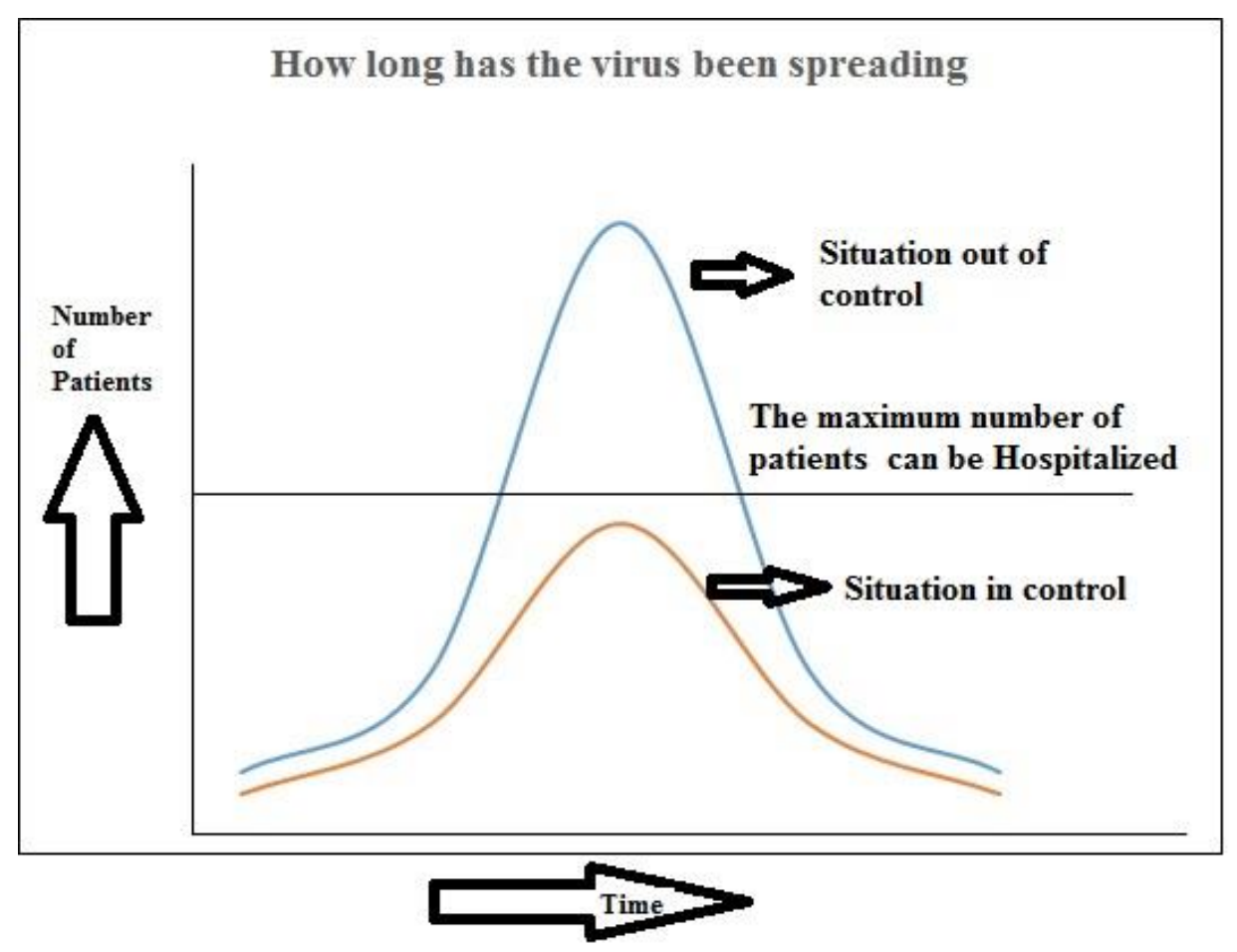

Figure 5. Graph showing the number of patients against the time with consideration of two situations

Figure 6 shows the COVID-19 situation reports based on the WHO database. The trend line shows that the number of affected people is increasing exponentially daily. Further, due to such a distressing situation, lockdowns and curfews are a common practice throughout the globe. On 
International Journal of Mathematical, Engineering and Management Sciences

Vol. 5, No. 6, 1156-1169, 2020

https://doi.org/10.33889/IJMEMS.2020.5.6.088

January 20th, 2020, WHO declared the presence of 282 COVID-19 infected people and from Figure 6 , it is quite distinct that the situation has worsened since then. Figure 6 also shows a comparison among the number of cases in China, India and Globally. It is well-known and comprehensible that the first case was reported in China, after which it increased and took a sharp spread over the globe. Also, initially, the situation was not under control in China, but as the reports of the infected rose sharply, China succeeded in controlling this epidemic in their region by taking radical measures. However, the virus spread increased and is still worsening in other regions of the world. Table 2 summarises the recent studies of COVID-19 based on the Scopus ${ }^{\circledR}$ database. The articles listed in table 2 have at least ten citations, according to the Scopus ${ }^{\circledR}$ database.
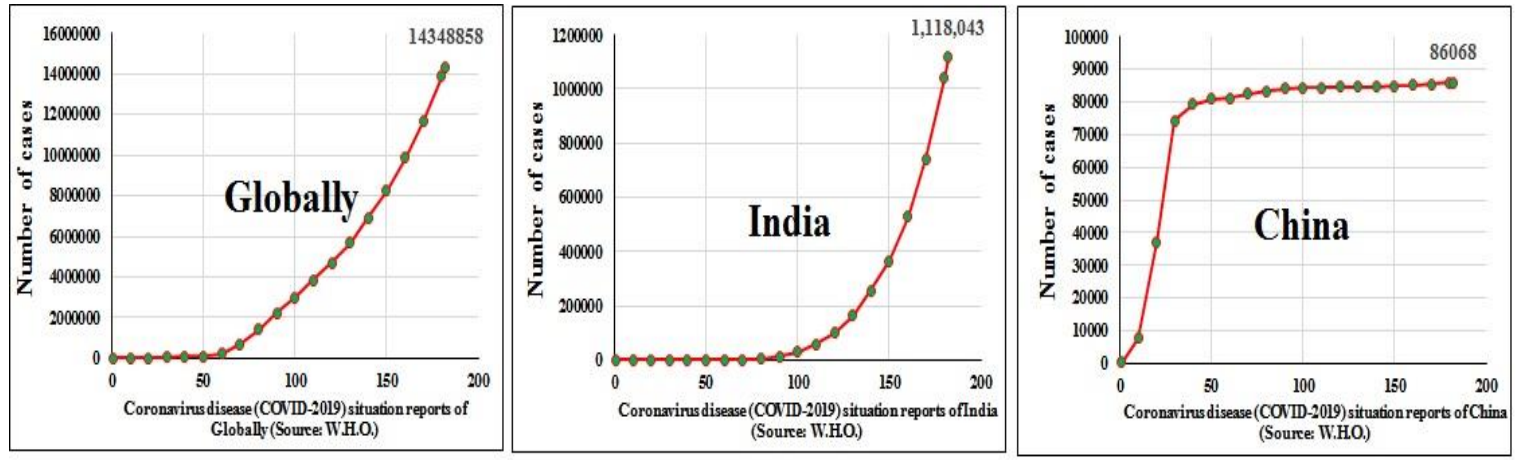

Figure 6. Comparison of total worldwide COVID-19 cases with India and China on every $10^{\text {th }}$ situation report of W.H.O.

Table 2. High impact articles on COVID-19

\begin{tabular}{|c|c|c|}
\hline S.No. & Authors & ndings \\
\hline 1. & Huang et al. (2020) & $\begin{array}{l}\text { This study reported the "epidemiological, clinical, laboratory, and radiological characteristics and } \\
\text { treatment and clinical outcomes of affected patients in Wuhan, China". }\end{array}$ \\
\hline 2. & Zhu et al. (2020) & The analyses of this study provide evidence "implicating 2019-nCoV in the Wuhan outbreak". \\
\hline 3. & Chen et al. (2020 a) & $\begin{array}{l}\text { This study concluded that "the infection of } 2019-\mathrm{nCoV} \text { was of clustering onset, is more likely to } \\
\text { infect older men with comorbidities, and can result in severe and even fatal respiratory diseases } \\
\text { such as ARDS". }\end{array}$ \\
\hline 4. & Chan et al. (2020 a) & $\begin{array}{l}\text { "The epidemiological, clinical, laboratory, radiological, and microbiological findings of } \\
\text { unexplained pneumonia in a Shenzhen family cluster connected to a Wuhan hospital" were } \\
\text { presented. }\end{array}$ \\
\hline 5. & $(2020)$ & $\begin{array}{l}\text { This study reported "the identification and characterisation of a new coronavirus (2019-nCoV), } \\
\text { which caused an epidemic of acute respiratory syndrome in humans in Wuhan, China." }\end{array}$ \\
\hline 6. & (2020) & $\begin{array}{l}\text { This study described "the genomic characteristics of } 2019-\mathrm{nCoV} \text { and similarities and differences } \\
\text { to other coronaviruses, including the virus that caused the severe acute respiratory syndrome } \\
\text { epidemic of } 2002-03 \text {. Genome sequences of } 2019-\mathrm{nCoV} \text { sampled from nine patients who were } \\
\text { among the early cases of this severe infection are almost genetically identical, which suggested a } \\
\text { very recent emergence of this virus in humans and that the outbreak was detected relatively } \\
\text { rapidly". }\end{array}$ \\
\hline 7. & $\begin{array}{l}\text { Holshue et al. } \\
(2020)\end{array}$ & $\begin{array}{l}\text { This study reported, "the first case of } 2019-\mathrm{nCoV} \text { infection confirmed in the United States and } \\
\text { described the identification, diagnosis, clinical course, and management of the case, including the } \\
\text { patient's initial mild symptoms at presentation with progression to pneumonia on day } 9 \text { of } \\
\text { illness". }\end{array}$ \\
\hline 8. & Wu et al. (2020) & $\begin{array}{l}\text { A study of "a single patient who was a worker at the market and who was admitted to the Central } \\
\text { Hospital of Wuhan on December 26th } 2019 \text { while experiencing a severe respiratory syndrome } \\
\text { that included fever, dizziness and a cough" was presented. }\end{array}$ \\
\hline 9. & (2020) & $\begin{array}{l}\text { Here, the authors analysed "the potential receptor usage by } 2019-\mathrm{nCoV} \text {, based on the rich } \\
\text { knowledge about SARS-CoV and the newly released sequence of } 2019-\mathrm{nCoV} \text { ". }\end{array}$ \\
\hline
\end{tabular}


International Journal of Mathematical, Engineering and Management Sciences

Vol. 5, No. 6, 1156-1169, 2020

https://doi.org/10.33889/IJMEMS.2020.5.6.088

Table 2 continued...

\begin{tabular}{|c|c|c|}
\hline 10. & Chen et al. (2020b) & $\begin{array}{l}\text { This research reported "the study of nine patients who had a caesarean section in their third } \\
\text { trimester. Seven patients presented with a fever. Other symptoms, including cough (in four of } \\
\text { nine patients), myalgia (in three), sore throat (in two), and malaise (in two)," were also observed. }\end{array}$ \\
\hline 11. & Ji et al. (2020) & $\begin{array}{l}\text { An "evolutionary analysis using } 272 \text { genomic sequences of coronaviruses obtained from various } \\
\text { geographic locations was performed. The results showed that the novel coronavirus sequence } \\
\text { obtained from the viral pneumonia outbreak occurring in the city of Wuhan forms a separate } \\
\text { group that is highly distinctive to SARS-CoV". }\end{array}$ \\
\hline 12. & Chen et al. (2020c) & This study introduced the general features of coronaviruses. \\
\hline 13. & Chan et al. (2020b) & $\begin{array}{l}\text { A bioinformatics analysis on a virus genome from a patient with } 2019-\mathrm{nCoV} \text { infection was } \\
\text { performed and compared with other related coronavirus genomes. }\end{array}$ \\
\hline 14. & $\begin{array}{l}\text { Munster et al. } \\
(2020)\end{array}$ & $\begin{array}{l}\text { This study highlighted "the ongoing pandemic and concluded that Epidemiologic information on } \\
\text { the pathogenicity and transmissibility of this virus obtained through molecular detection and } \\
\text { serosurveillance is needed to fill in the details in the surveillance pyramid and guide the response } \\
\text { to this outbreak". Moreover, the study suggested that "the propensity of novel coronaviruses to } \\
\text { spread in health care centers indicates a need for peripheral health care facilities to be on standby } \\
\text { to identify potential cases as well". }\end{array}$ \\
\hline 15. & Chung et al. (2020) & $\begin{array}{l}\text { This work represents "an early investigation of chest C.T. findings in the } 2019 \text { novel coronavirus } \\
\text { (2019-nCoV), intending to create familiarity with common imaging manifestations of the } \\
\text { disease". Further, the study says that "the radiologist plays a crucial role in the rapid identification } \\
\text { and early diagnosis of new cases, which can be of great benefit not only to the patient but to the } \\
\text { larger public health surveillance and response systems". }\end{array}$ \\
\hline 16. & Xu et al. (2020a) & $\begin{array}{l}\text { This showed that "the Wuhan CoV shared with the SARS/SARS-like coronaviruses a common } \\
\text { ancestor that resembles the bat coronavirus HKU9-1". }\end{array}$ \\
\hline 17. & Russell et al. (2020) & $\begin{array}{l}\text { The authors concluded that "corticosteroid treatment should not be used for the treatment of 2019- } \\
\text { nCoV-induced lung injury or shock outside of a clinical trial". }\end{array}$ \\
\hline 18. & $\mathrm{Xu}$ et al. (2020b) & $\begin{array}{l}\text { This study is under regulations issued by the National Health Commission of China and the } \\
\text { Helsinki Declaration. The authors quoted that their findings will "facilitate understanding of the } \\
\text { pathogenesis of COVID-19 and improve clinical strategies against the disease". }\end{array}$ \\
\hline 19. & Zou et al. (2020) & $\begin{array}{l}\text { This study analysed "the viral load in nasal and throat swabs obtained from the } 17 \text { symptomatic } \\
\text { patients with the day of onset of any symptoms". }\end{array}$ \\
\hline 20. & Wang et al. (2020b) & $\begin{array}{l}\text { The study enlightened the readers through their article in which they clarified the disease and } \\
\text { said: "the 2019-nCoV infection is spreading fast with an increasing number of infected patients } \\
\text { nationwide". Also, "the future development of the disease is not clear but the public should be } \\
\text { cautious in dealing with the virus since it may be very contagious. The first occurred deaths were } \\
\text { majorly elderly people who might have faster disease progression. The public should pay more } \\
\text { attention to protecting elderly people who have contracted the virus." }\end{array}$ \\
\hline 21. & Bai et al. (2020) & $\begin{array}{l}\text { The authors observed that "all symptomatic patients had multifocal ground-glass opacities on } \\
\text { chest C.T., and } 1 \text { also had subsegmental areas of consolidation and fibrosis. All the symptomatic } \\
\text { patients had increased C-reactive protein levels and reduced lymphocyte counts." }\end{array}$ \\
\hline 22. & $\begin{array}{l}\text { Gralinski and } \\
\text { Menachery (2020) }\end{array}$ & $\begin{array}{l}\text { The authors thought that "the emergence of a novel coronavirus (2019-nCoV) has awakened the } \\
\text { echoes of SARS-CoV from nearly two decades ago. Yet, with technological advances and } \\
\text { important lessons gained from previous outbreaks, perhaps the world is better equipped to deal } \\
\text { with the most recent emergent group } 2 \text { B coronavirus". }\end{array}$ \\
\hline 23. & $\begin{array}{l}\text { Riou and Althaus } \\
(2020)\end{array}$ & $\begin{array}{l}\text { The analysis suggested that "the early pattern of human-to-human transmission of } 2019 \text {-nCoV is } \\
\text { reminiscent of SARS-CoV emergence in } 2002 \text {. International collaboration and coordination will } \\
\text { be crucial to contain the spread of } 2019-\mathrm{nCoV}^{\prime} \text {. }\end{array}$ \\
\hline 24. & Lai et al. (2020) & $\begin{array}{l}\text { The study suggested that "the disease is a clinical threat and suggested that one should } \\
\text { aggressively implement infection control measures to prevent the spread of SARS-CoV-2 via } \\
\text { human-to-human transmission". }\end{array}$ \\
\hline 25. & Backer et al. (2020) & $\begin{array}{l}\text { This study characterised "the distribution of incubation periods for travelers from Wuhan infected } \\
\text { with 2019-nCoV who were reported as cases between } 20 \text { and } 28 \text { January } 2020 \text { ". }\end{array}$ \\
\hline 26. & Lei et al. (2020) & $\begin{array}{l}\text { In this article, on "the basis of epidemiologic characteristics, clinical manifestations, chest } \\
\text { images, and laboratory findings, the diagnosis of } 2019-\mathrm{nCoV} \text { pneumonia" was made. "After } \\
\text { receiving } 3 \text { days of treatment, combined with interferon inhalation, the patient was clinically } \\
\text { worse with progressive pulmonary opacities found at repeat chest C.T.". }\end{array}$ \\
\hline 27. & Song et al. (2020) & $\begin{array}{l}\text { This study clarified that "nearly all patients in this series with } 2019 \text { Novel Coronavirus, or 2019- } \\
\text { nCoV, pneumonia ( } 50 \text { of } 51 \text { patients, } 98 \% \text { ) had a history of contact with individuals from Wuhan, } \\
\text { China. Further, Chest CT showed pure ground-glass opacities (G.G.O.s) in } 77 \% \text { of patients, } \\
\text { G.G.O.s with interstitial and/or interlobular septal thickening in } 75 \% \text { of patients, and G.G.O.s } \\
\text { with consolidation in } 59 \% \text { of patients. A chest CT, G.G.O.s were bilateral in } 88 \% \text { of patients, } \\
\text { involving the posterior lungs in } 82 \% \text { and the peripheral lungs in } 85 \% \text { of patients". }\end{array}$ \\
\hline
\end{tabular}


International Journal of Mathematical, Engineering and Management Sciences

Vol. 5, No. 6, 1156-1169, 2020

https://doi.org/10.33889/IJMEMS.2020.5.6.088

Table 2 continued...

\begin{tabular}{|c|c|c|}
\hline 28. & Bogoch et al. (2020) & $\begin{array}{l}\text { This study evaluated "the potential for international dissemination of this disease via commercial } \\
\text { air travel should the outbreak continue". }\end{array}$ \\
\hline 29. & Liang et al. (2020) & $\begin{array}{l}\text { "Three major strategies for patients with cancer in this COVID-19 crisis, and in future attacks of } \\
\text { severe infectious diseases" was proposed. }\end{array}$ \\
\hline 30. & Wax et al. (2020) & 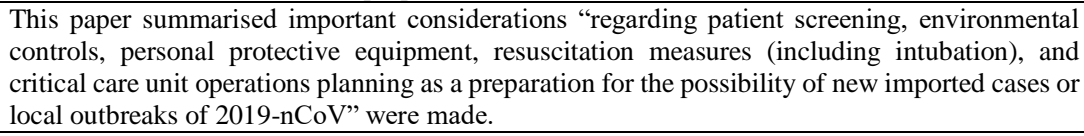 \\
\hline 31. & Zhang et al. (2020a) & $\begin{array}{l}\text { Detailed clinical investigation of " } 140 \text { hospitalised COVID-19 cases suggests eosinopenia } \\
\text { together with lymphopenia may be a potential indicator for diagnosis. Allergic diseases, asthma, } \\
\text { and COPD are not risk factors for SARS-CoV-2 infection. Older age, a high number of } \\
\text { comorbidities, and more prominent laboratory abnormalities were associated with severe } \\
\text { patients". }\end{array}$ \\
\hline 32. & Kim et al. (2020) & $\begin{array}{l}\text { This report suggested that "in the early phase of } 2019-\mathrm{nCoV} \text { pneumonia, chest radiography would } \\
\text { miss patients with pneumonia and highlighted that taking travel history is of paramount } \\
\text { importance for early detection and isolation of } 2019-\mathrm{nCoV} \text { cases". }\end{array}$ \\
\hline 33. & Zhang et al. (2020b) & $\begin{array}{l}\text { An investigation was conducted on patients in a local hospital who were infected with this virus. } \\
\text { "The presence of } 2019-n C o V \text { in anal swabs and blood as well, and more anal swab positives than } \\
\text { oral swab positives in a later stage of infection, suggesting shedding and thereby transmitted } \\
\text { through oral-fecal route was found. It was also showed that the serology test can improve } \\
\text { detection positive rate thus should be used in future epidemiology. Our report provides a } \\
\text { cautionary warning that } 2019 \text {-nCoV maybe shed through multiple routes". }\end{array}$ \\
\hline
\end{tabular}

\section{Discussion}

\subsection{Characteristics of Coronavirus and COVID-19 Infection}

COVID-19 is spreading globally. It falls under a large family of viruses that can cause illness in animals and humans. COVID-19 belongs to the order Nidovirales and family Coronaviridae (Chan et al., 2020b; Lu et al., 2020). The name Corona comes after the crown-like enveloped structure consists of a single layer of lipid. Envelop of Coronavirus contains positive sense, single-stranded R.N.A. (+ssRNA) as a genetic material of 27-32 kb in size (Chan et al., 2020b; Lu et al., 2020). In humans, respiratory infections such as common cold to some of the severe diseases including Severe Acute Respiratory Syndrome (SARS) and Middle East Respiratory Syndrome (MERS) are known to be caused due to this family of viruses. Recently, COVID-19 is discovered as a highly infectious disease caused by coronaviruses. SARS and COVID-19 are different from each other, as no outbreak has been seen of SARS since 2013. The virus and disease COVID-19 were not reported before the outbreak arises in Wuhan, China, in December 2019. The increased replication fidelity is believed to be due to the expanded genome size of COVID-19 over other viruses. The genetic expansion of COVID-19 leads to the acquisition of accessory proteins coding genes that provide benefits to the virus for host adaptation. Consequently, the genetic changes caused by gene insertion or deletion, gene interchange, and recombination are frequent among coronaviruses (Chen et al., 2020c). Coronavirus disease (COVID-19 or 2019-nCoV) is a highly infectious disease which is caused by a novel virus. Bats are believed to be the possible transmitters (Zhou et al., 2020). Bats often possess a higher percentage of zoonotic viruses compared to other mammalian orders ( $\mathrm{Ji}$ et al., 2020). A wide investigation on relationships between mammalian hosts and viruses hypothesised that flight ability of bats gives the selection pressure for coexistence with the virus (Zhou et al., 2020). Certainly, bats were known for a carrier of few highly pathogenic human diseases viruses such as henipaviruses (Nipah virus), bat lyssaviruses (Rabies virus) and of course the coronaviruses (SADS-CoV, MERS-CoV, and SARS-CoV) (Ji et al., 2020; Zhou et al., 2020). Most of the persons diseased with the COVID-19 virus will encounter slight to temperate respiratory problems and recuperate without needing distinct treatment. Aged people and those with multiple medical problems like cancer, diabetes, cardiovascular disease, and chronic 
International Journal of Mathematical, Engineering and Management Sciences

Vol. 5, No. 6, 1156-1169, 2020

https://doi.org/10.33889/IJMEMS.2020.5.6.088

respiratory diseases are more prone to grow stern sickness (Wang et al., 2020a). The disease in advanced cases leads to acute respiratory problems (like flu) with major signs such as fever, cough, and in further severe cases, it leads to difficulty in breathing (Chen et al., 2020a, Huang et al., 2020; Zhang et al., 2020). The other symptoms that have also been reported by other patients infected with COVID-19 are nasal congestion, pains, and aches, runny nose, diarrhea or sore throat (Huang et al., 2020). The person suffering from COVID-19 may experience initial mild symptoms with a gradual increase. According to the report of WHO, one infected person could infect 2-5 people on an average. The aged person or people having health issues such as immuno-compromised (weak immunity), cancer, diabetes, heart problems, kidney failure or high blood pressure are highly prone to this disease (Wang et al., 2020a; Liang et al., 2020). The disease mainly spreads through communication with a diseased individual by coughing and sneezing (droplet spread) and also by touching, kissing, and physical contact (Riou and Althaus, 2020). Airborne transmission has not yet been reported. The COVID-19 has an incubation period of approximately 7-14 days depending upon the immunity and age of host animals, while most commonly around 5 days (Backer et al., 2020). Since the rapid detection test kits for detection of COVID-19 is under development; therefore, people facing problems such as difficulty in breathing, dry cough, and fever need medical attention. The only solution one can suggest is by keeping isolated from the infectious environment, social distancing. Individuals can most crucially protect themselves by cleaning and washing their hands quite often, evading touching of the face, and dodging close contact ( 1 meter or 3 feet) with the patients (Wu and McGoogan, 2020). The novel coronavirus (2019-nCoV) eruption, which originally instigated in China, has spread to numerous countries around the globe, with the number of established cases growing daily. With a death number beyond that of the SARS-CoV eruption back in 2002 and 2003 in China, 2019-nCoV has run to a civic health emergency of international apprehension, setting all health institutions on high alert. Coronaviruses classically end in respiratory and enteric corruptions upsetting together animals and humans. At this juncture, there are no treatments or vaccines or for COVID-19. Nonetheless, several continuing medical trials are accessing probable treatments. Remdesivir, an antiviral medicine advanced for the management of the Ebola virus disease, was used for the management of the first U.S. case of 2019-nCoV (Holshue et al., 2020). A continuing randomised controlled trial accessing the effectiveness and safety of lopinavir-ritonavir and interferon- $\alpha 2 \mathrm{~b}$ was started on January 10th, 2020. Nonetheless, segregation and supportive attention including fluid management, oxygen therapy and supervision of antimicrobials for the handling of secondary bacterial contaminations to improve the symptoms and avert end-organ dysfunction is presently suggested by WHO for alleged and established cases needing hospital admission.

\subsection{COVID-19: A Boon for the Environment and a Bane for Mankind}

Indubitably, the COVID-19 pandemic has shaken the whole world, despite such destruction the air pollution is slashing at most of the places around the globe. The temporary halt throughout the globe has brought to the forefront surprising climate changes including fewer carbon-emissions. Also, the satellite images (European Space Agency) showed a dramatic decrease in the atmospheric nitrous oxide. The premature deaths due to air pollution are around 4.6 million (World Health Organization). Surprisingly, due to temporary and preventive measures of COVID-19, the quality of air has significantly improved in various areas throughout the globe. For instance, NASA and the European Space Agency (E.S.A.) pollution monitoring satellites have detected significant decreases in nitrogen dioxide (NO2) over China. The change in these $\mathrm{NO}_{2}$ levels is closely related to the global halt. However, such events can still not be considered a silver lining for the environment. 
International Journal of Mathematical, Engineering and Management Sciences

Vol. 5, No. 6, 1156-1169, 2020

https://doi.org/10.33889/IJMEMS.2020.5.6.088

\subsection{COVID-19 in Indian Context}

India is going through a crucial juncture with its fight against COVID-19. The well-known responsive measures against this pandemic are to find, isolate, test, treat, and trace. The total number of infected personals in India is rising rapidly and spreading a stressful situation nationwide. The average age of deaths caused by COVID-19 in India till April 06 ${ }^{\text {th, }} 2020$, was 60 years. The case fatality rate or the case fatality ratio is calculated as the fraction of deaths among all the diagnosed cases over a certain period. The overall C.F.R. comes out to be $2.7 \%$ which is aligned with the trend in other countries. As per the study of the ICMR, 9.4\% of the country is diabetic which signifies the fact that diabetes emerged as the leading co-morbidity among the deaths due to COVID-19 (Gupta and Misra, 2020). Though, the country has responded to this pandemic through a determined step of National Lockdown. However, once the lockdown is discontinued the Government is in a vulnerable situation and dealing with the hardships of the lockdown. Undoubtedly, a lockdown of this enormous magnitude will not be without cost. A proper agenda will be required to deal with the repercussion of the national lockdown. One of the severe challenges is to ensure that the poor and daily wage workers who are prevented from working for longer periods can survive. As per the Centre of Monitoring the Indian Economy (CMIE), the nationwide lockdown witnessed the joblessness rate to nearly triplicating and quadrupling in the urban areas. The unemployment rate was already at a terrifying $8.7 \%$ in March, and with the lockdown, it gushed up to $23.8 \%$. On a positive note, every crisis provides the opportunity to learn. Certainly, the virus has disrupted human life and the global economy, but the efforts to contain this virus through various restrictions have remarkably influenced the environment positively. The reduced emissions due to the transport sector and strike in other emissions-related activities are gradually minimising the air pollutants. Though this is not an ideal way to curb pollution but it is evident that air pollution is manmade.

\section{Conclusion}

The present review paper presents an overview of the literature on coronaviruses since the beginning. The analysis presented in this review provides interesting insights regarding the past and progress of this pandemic in the world. The Scopus database is used to perform this review study. The study highlights the most contributed authors, institutions, countries and their interrelation in a way that has not presented before in this regard. An elongated discussion is included to give an insight into COVID-19 from scratch. The Novel outbreak of COVID-19 disease has some very high research scopes particularly required for its prevention, cure and efficient dealing. Research studies focusing on curtailing the ongoing outbreak and preventing future outbreaks of such kind is the most pressing need. One of the immediate extensions would be to develop a review study by using medical databases like PubMed, EMBASE, etc. Moreover, looking towards the social impact of this disease, the rural enterprise has severely affected due to various Government policies viz. curfew, lockdowns, restrictions, etc. So, a distinct and worthwhile research direction would be to give policy dimensions for the betterment of rural enterprises.

\footnotetext{
Conflict of Interest

The authors declare that they have no known competing financial interests or personal relationships that could have appeared to influence the work reported in this paper.
}

\section{Acknowledgements}

The authors would like to thank the editor and referees for their valuable input in our research. We take this opportunity to express our sincere gratitude to all the medical and healthcare professionals. 
International Journal of Mathematical, Engineering and Management Sciences

Vol. 5, No. 6, 1156-1169, 2020

https://doi.org/10.33889/IJMEMS.2020.5.6.088

\section{References}

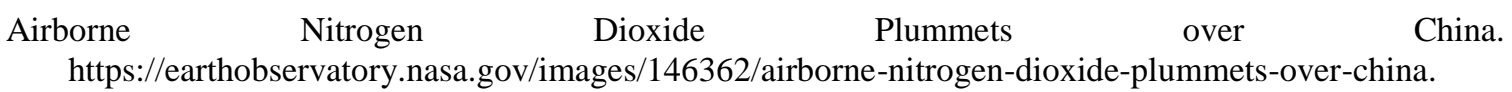

Backer, J.A., Klinkenberg, D., \& Wallinga, J. (2020). Incubation period of 2019 novel coronavirus (2019$\mathrm{nCoV}$ ) infections among travellers from Wuhan, China, 20-28 January 2020. Eurosurveillance, 25(5), 2000062. DOI: 10.2807/1560-7917.ES.2020.25.5.2000062.

Bai, Y., Yao, L., Wei, T., Tian, F., Jin, D.Y., Chen, L., \& Wang, M. (2020). Presumed asymptomatic carrier transmission of COVID-19. Jama, 323(14), 1406-1407. https://doi.org/10.1001/jama.2020.2565.

Bogoch, I.I., Watts, A., Thomas-Bachli, A., Huber, C., Kraemer, M.U.G., \& Khan, K. (2020). Pneumonia of unknown aetiology in Wuhan, China: Potential for international spread via commercial air travel. Journal of Travel Medicine, 27(2), 1-3. https://doi.org/10.1093/jtm/taaa008.

Chan, J.F.W., Kok, K.H., Zhu, Z., Chu, H., To, K.K.W., Yuan, S., \& Yuen, K.Y. (2020b). Genomic characterisation of the 2019 novel human-pathogenic coronavirus isolated from a patient with atypical pneumonia after visiting Wuhan. Emerging Microbes and Infections, 9(1), 221-236. https://doi.org/10.1080/22221751.2020.1719902.

Chan, J.F.W., Yuan, S., Kok, K.H., To, K.K.W., Chu, H., Yang, J., ... Yuen, K.Y. (2020a). A familial cluster of pneumonia associated with the 2019 novel coronavirus indicating person-to-person transmission: a study of a family cluster. The Lancet, 395(10223), 514-523. https://doi.org/10.1016/S01406736(20)30154-9.

Chen, H., Guo, J., Wang, C., Luo, F., Yu, X., Zhang, W., ... Zhang, Y. (2020b). Clinical characteristics and intrauterine vertical transmission potential of COVID-19 infection in nine pregnant women: a retrospective review of medical records. The Lancet, 395(10226), 809-815. https://doi.org/10.1016/S0140-6736(20)30360-3.

Chen, N., Zhou, M., Dong, X., Qu, J., Gong, F., Han, Y., ... Zhang, L. (2020a). Epidemiological and clinical characteristics of 99 cases of 2019 novel coronavirus pneumonia in Wuhan, China: a descriptive study. The Lancet, 395(10223), 507-513. https://doi.org/10.1016/S0140-6736(20)30211-7.

Chen, Y., Liu, Q., \& Guo, D. (2020c). Emerging coronaviruses: Genome structure, replication, and pathogenesis. Journal of Medical Virology, 92(4), 418-423. https://doi.org/10.1002/jmv.25681.

Chung, M., Bernheim, A., Mei, X., Zhang, N., Huang, M., Zeng, X., ... Shan, H. (2020). C.T. imaging features of 2019 novel coronavirus (2019-NCoV). Radiology, 295(1), 202-207. https://doi.org/10.1148/radiol.2020200230.

Gao, D., Xu, Z., Ruan, Y.Z., \& Lu, H. (2017). From a systematic literature review to integrated definition for sustainable supply chain innovation (SSCI). Journal of Cleaner Production, 142, 1518-1538. https://doi.org/10.1016/j.jclepro.2016.11.153.

Gralinski, L.E., \& Menachery, V.D. (2020). Return of the Coronavirus: 2019-nCoV. Viruses, $12(2), 135$. DOI: https://doi.org/10.3390/v12020135.

Gupta, R., \& Misra, A. (2020). Contentious issues and evolving concepts in the clinical presentation and management of patients with COVID-19 infectionwith reference to use of therapeutic and other drugs used in Co-morbid diseases (Hypertension, diabetes etc). Diabetes and Metabolic Syndrome: Clinical Research and Reviews, 14(3), 251-254. https://doi.org/10.1016/j.dsx.2020.03.012.

Holshue, M.L., DeBolt, C., Lindquist, S., Lofy, K.H., Wiesman, J., Bruce, H., ... Pillai, S.K. (2020). First case of 2019 novel coronavirus in the United States. New England Journal of Medicine, 382(10), 929936. https://doi.org/10.1056/NEJMoa2001191. 
International Journal of Mathematical, Engineering and Management Sciences

Vol. 5, No. 6, 1156-1169, 2020

https://doi.org/10.33889/IJMEMS.2020.5.6.088

Huang, C., Wang, Y., Li, X., Ren, L., Zhao, J., Hu, Y., ... Cao, B. (2020). Clinical features of patients infected with 2019 novel coronavirus in Wuhan, China. The Lancet, 395(10223), 497-506. https://doi.org/10.1016/S0140-6736(20)30183-5.

Ji, W., Wang, W., Zhao, X., Zai, J., \& Li, X. (2020). Cross-species transmission of the newly identified coronavirus 2019-nCoV. Journal of Medical Virology, 92(4), 433-440. https://doi.org/10.1002/jmv.25682.

Kim, J.Y., Choe, P.G., Oh, Y., Oh, K.J., Kim, J., Park, S.J., .. Oh, M.D. (2020). The first case of 2019 novel coronavirus pneumonia imported into korea from wuhan, china: Implication for infection prevention and control measures. Journal of Korean Medical Science, 35(5), 1-4. https://doi.org/10.3346/jkms.2020.35.e61.

Lai, C.C., Shih, T.P., Ko, W.C., Tang, H.J., \& Hsueh, P.R. (2020). Severe acute respiratory syndrome coronavirus 2 (SARS-CoV-2) and coronavirus disease-2019 (COVID-19): The epidemic and the challenges. International Journal of Antimicrobial Agents, 55(3), 105924. https://doi.org/10.1016/j.ijantimicag.2020.105924.

Lei, J., Li, J., Li, X., \& Qi, X. (2020). C.T. imaging of the 2019 novel coronavirus (2019-nCoV) pneumonia. Radiology, 295(1), 18-18. https://doi.org/10.1148/radiol.2020200236.

Liang, W., Guan, W., Chen, R., Wang, W., Li, J., Xu, K., ... He, J. (2020). Cancer patients in SARS-CoV-2 infection: a nationwide analysis in China. The Lancet Oncology, 21(3), 335-337. https://doi.org/10.1016/S1470-2045(20)30096-6.

Lu, R., Zhao, X., Li, J., Niu, P., Yang, B., Wu, H., ... Tan, W. (2020). Genomic characterisation and epidemiology of 2019 novel coronavirus: implications for virus origins and receptor binding. The Lancet, 395(10224), 565-574. https://doi.org/10.1016/S0140-6736(20)30251-8.

Mayring, P. (2000). Qualitative content analysis. Forum: Qualitative Social Research, 1(2), $105-114$. https://www.qualitative-research.net/index.php/fqs/article/view/1089/2385.

Munster, V.J., Koopmans, M., van Doremalen, N., van Riel, D., \& de Wit, E. (2020). A novel coronavirus emerging in China - Key questions for impact assessment. New England Journal of Medicine, 382(8), 692-694. https://doi.org/10.1056/NEJMp2000929.

Riou, J., \& Althaus, C.L. (2020). Pattern of early human-to-human transmission of Wuhan 2019 novel coronavirus (2019-nCoV), December 2019 to January 2020. Eurosurveillance, 25(4), 1-5. https://doi.org/10.2807/1560-7917.ES.2020.25.4.2000058.

Rushdi, A.M.A., \& Serag, H.A.M. (2020). Solutions of ternary problems of conditional probability with applications to mathematical epidemiology and the COVID-19 pandemic. International Journal of Mathematical, Engineering and Management Sciences, 5(5), 787-811. https://doi.org/10.33889/ijmems.2020.5.5.062.

Russell, C.D., Millar, J.E., \& Baillie, J.K. (2020). Clinical evidence does not support corticosteroid treatment for 2019-nCoV lung injury. The Lancet, 395(10223), 473-475. https://doi.org/10.1016/S01406736(20)30317-2.

Seuring, S., \& Müller, M. (2008). From a literature review to a conceptual framework for sustainable supply chain management. Journal of Cleaner Production, 16(15), 1699-1710. https://doi.org/10.1016/j.jclepro.2008.04.020.

Song, F., Shi, N., Shan, F., Zhang, Z., Shen, J., Lu, H., ... Shi, Y. (2020). Emerging 2019 novel coronavirus (2019-NCoV) pneumonia. Radiology, 295(1), 210-217. https://doi.org/10.1148/radiol.2020200274.

Van Eck, N.J., \& Waltman, L. (2010). Software survey: VOSviewer, a computer program for bibliometric mapping. Scientometrics, 84(2), 523-538. https://doi.org/10.1007/s11192-009-0146-3. 
International Journal of Mathematical, Engineering and Management Sciences

Vol. 5, No. 6, 1156-1169, 2020

https://doi.org/10.33889/IJMEMS.2020.5.6.088

Wan, Y., Shang, J., Graham, R., Baric, R.S., \& Li, F. (2020). Receptor Recognition by the novel coronavirus from Wuhan: an analysis based on decade-long structural studies of SARS coronavirus. Journal of Virology, 94(7), 1-9. https://doi.org/10.1128/jvi.00127-20.

Wang, L., Wang, Y., Ye, D., \& Liu, Q. (2020a). Review of the 2019 novel coronavirus (SARS-CoV-2) based on current evidence. International Journal of Antimicrobial Agents, 55(6), 105948. https://doi.org/10.1016/j.ijantimicag.2020.105948.

Wang, W., Tang, J., \& Wei, F. (2020b). Updated understanding of the outbreak of 2019 novel coronavirus (2019-nCoV) in Wuhan, China. Journal of Medical Virology, 92(4), 441-447. https://doi.org/10.1002/jmv.25689.

Wax, R.S., \& Christian, M.D. (2020). Practical recommendations for critical care and anesthesiology teams caring for novel coronavirus (2019-nCoV) patients. Canadian Journal of Anesthesia, 67(5), 568-576. https://doi.org/10.1007/s12630-020-01591-x.

Wu, F., Zhao, S., Yu, B., Chen, Y.M., Wang, W., Song, Z.G., ... Zhang, Y.Z. (2020). A new coronavirus associated with human respiratory disease in China. Nature, 579(7798), 265-269. https://doi.org/10.1038/s41586-020-2008-3.

Wu, Z., \& McGoogan, J.M. (2020). Characteristics of and important lessons from the Coronavirus disease 2019 (COVID-19) outbreak in China: summary of a report of 72314 cases from the Chinese center for disease control and prevention. JAMA - Journal of the American Medical Association, 323(13), 12391242. https://doi.org/10.1001/jama.2020.2648.

Xu, X., Chen, P., Wang, J., Feng, J., Zhou, H., Li, X., ... Hao, P. (2020a). Evolution of the novel coronavirus from the ongoing Wuhan outbreak and modeling of its spike protein for risk of human transmission. Science China Life Sciences, 63(3), 457-460. https://doi.org/10.1007/s11427-020-1637-5.

Xu, Z., Shi, L., Wang, Y., Zhang, J., Huang, L., Zhang, C., ... Wang, F.S. (2020b). Pathological findings of COVID-19 associated with acute respiratory distress syndrome. The Lancet Respiratory Medicine, 8(4), 420-422. https://doi.org/10.1016/S2213-2600(20)30076-X.

Zhang, J.-J., Dong, X., Cao, Y.Y., Yuan, Y.D., Yang, Y.-B., Yan, Y. Q., Cezmi, A.A., \& Gao, Y.D. (2020a). Clinical characteristics of 140 patients infected with SARS-CoV-2 in Wuhan, China. Allergy: European Journal of Allergy and Clinical Immunology, (February), 1-12. https://doi.org/10.1111/all.14238.

Zhang, W., Du, R.H., Li, B., Zheng, X.S., Yang, X.-L., Hu, B., Wang, Y.Y., Xiao, G.-F., Yan, B., Shi, Z.-L. $\&$ Zhou, P. (2020b). Molecular and serological investigation of 2019-nCoV infected patients: implication of multiple shedding routes. Emerging Microbes and Infections, 9(1), 386-389. https://doi.org/10.1080/22221751.2020.1729071.

Zhou, P., Yang, X.-L., Wang, X.-G., Hu, B., Zhang, L., Zhang, W., ... Shi, Z.L. (2020). A pneumonia outbreak associated with a new coronavirus of probable bat origin. Nature, 579(7798), 270-273. https://doi.org/10.1038/s41586-020-2012-7.

Zhu, N., Zhang, D., Wang, W., Li, X., Yang, B., Song, J., ... Tan, W. (2020). A novel coronavirus from patients with pneumonia in China, 2019. New England Journal of Medicine, 382(8), 727-733. https://doi.org/10.1056/NEJMoa2001017.

Zou, L., Ruan, F., Huang, M., Liang, L., Huang, H., Hong, Z., ... \& Guo, Q. (2020). SARS-CoV-2 viral load in upper respiratory specimens of infected patients. New England Journal of Medicine, 382(12), 11771179. https://doi.org/10.1056/NEJMc2001737. 